\title{
Bioaccumulation and Translocation of Heavy Metals from Coastal Soil by Wild Halophytes
}

\author{
Yasser A. El-Amier ${ }^{1, *}$, Suliman M. Alghanem ${ }^{2}$, Fahad M. Alzuaibr ${ }^{2}$ \\ ${ }^{1}$ Botany Department, Faculty of Science, Mansoura University, Mansoura, Egypt \\ ${ }^{2}$ Biology Department, Faculty of Science, Tabuk University, Tabuk, KSA \\ *Corresponding author: yasran@mans.edu.eg
}

\begin{abstract}
In the present study, six native halophytes were collected from soil of northern Nile Delta to evaluate their phytoremediation potential of heavy metals. For this purpose, soil, the aboveground parts and roots of the samples were analyzed for total concentrations of $\mathrm{Fe}, \mathrm{Pb}, \mathrm{Ni}, \mathrm{Co}$ and $\mathrm{Cd}$ using atomic absorption spectrometer. The concentrations of different heavy metals in soils have the sequence of $\mathrm{Fe}>\mathrm{Ni}>\mathrm{Pb}>\mathrm{Co}>\mathrm{Cd}$. The pollution quantification for each metal in the study area indicated that, the extremely high enrichment value for $\mathrm{Cd}$; very high enrichment values for $\mathrm{Pb}$ and $\mathrm{Co}$ and low enrichment values for $\mathrm{Ni}$ and $\mathrm{Fe}$; The contamination factor has very high for $\mathrm{Cd}$; moderate for $\mathrm{Pb}$ and $\mathrm{Co}$ and low for $\mathrm{Ni}$ and $\mathrm{Fe}$, while the contamination degree (CD) indicates that the study area is considered to be coast with low to moderate contamination degree (2.74 and 10.29). In the study area, the concentrations of heavy metals in plant species have the order of $\mathrm{Fe}>\mathrm{Pb}>\mathrm{Ni}>\mathrm{Cd}>\mathrm{Co}$. Most plant species had a $\mathrm{TF}<1$ for $\mathrm{Fe}, \mathrm{Ni}$, $\mathrm{Co}$ and $\mathrm{Cd}$ except $\mathrm{Pb}>1$, while the $\mathrm{BAF}$ values for $\mathrm{Fe}, \mathrm{Pb}, \mathrm{Ni}$, $\mathrm{Co}$ and $\mathrm{Cd}$ were $<1$, except $\mathrm{BAF}$ root of A. halimus, L. pruinosum and S. pruinosa were $>1$. The highest BAF shoot and root values was observed in Atriplex halimus, while the lowest was for Suaeda maritima. Similarly, the highest TF values were observed for Z. aegyptium, $S$. pruinosa and L. monopetalum, while the lowest was for S. pruinosa. Results suggest that these plants could be suitable for use in the phytoremediation of contaminated soil sites.
\end{abstract}

Keywords: coastal desert, iron, lead, nickle, cadmium, cobalt, phytoremediation, soil indices

Cite This Article: Yasser A. El-Amier, Suliman M. Alghanem, and Fahad M. Alzuaibr, "Bioaccumulation and Translocation of Heavy Metals from Coastal Soil by Wild Halophytes." American Journal of Environmental Protection, vol. 5, no. 2 (2017): 52-60. doi: 10.12691/env-5-2-4.

\section{Introduction}

In recent years, the problem of environmental contamination by a wide variety of chemical pollutants including heavy metals been observed throughout the world because of toxicity and potential risk for human health [1]. Contamination with heavy metals are one of the main pollutants which affect the plants and animals throughout globe. Food and fodder crops raised on metal contaminated soils have the tendency to accumulate excessive amounts of heavy metals, which poses severe risk to human and animal health [2,3]. Heavy metal contents in plants are dependent on soil, climatic factors, agrochemical application, irrigation water quality, plant growth rates and plant parts [4,5]. Although heavy metals like $\mathrm{Cu}, \mathrm{Cr}$ and $\mathrm{Co}$ are vital for plant and animal metabolism, at levels above maximum permissible limits they disrupts the normal functioning of organisms $[6,7]$. $\mathrm{Cd}$ and $\mathrm{Pb}$ are known to be highly toxic and carcinogenic for animals and humans [8].

Bioavailability, bio-accumulation and translocation of metallic components in ecosystem are attaining great importance of study throughout the world [9]. Phytoremediation is a green technology and bioremediation by plants can be better option to remove toxicants from the polluted environment because plants have the ability to detoxify poisonous elements and to grow in degraded ecosystem. Plants can bio-accumulate metallic ions and dissolved chemicals by either root, leaf or stem and are arrested and sequestered into their tissues at least impermanently $[10,11]$. These chemicals arise from increasing levels of anthropogenic activities such as industrialization and urbanization, coal and metals ore mining, chemical manufacturing, petroleum mining and refining, electric power generation, melting and metal refining, metal plating and to some extent domestic sewage [12,13].

Previous studies showed that some plants are able to grow in these extreme environments and often are able to evolve into metal-tolerant ecotypes $[14,15,16]$. Halophytes are of important attention since these plants are naturally present in environments with an excess of toxic ions and research findings suggest that these plants also tolerate other environmental stresses, especially heavy metals as their tolerance to salt and to heavy metals may, at least partly, rely on common physiological mechanisms. Therefore, halophytic plants have been suggested to be naturally better adapted to overcome the heavy metals compared to glycophytic plants commonly chosen for phytoremediation research [17]. The present work aimed to study various native plant species in northern Nile Delta to evaluate their bioaccumulation and translocation of heavy metals. 


\section{Materials and Methods}

\subsection{Description of the Study Area}

The area chosen for the present study is located in the northern part of the Nile Delta region of Egypt (Figure 1). The Deltaic coast (middle section of the Mediterranean coast) extends from Abu-Quir (in the west, Long. $32^{\circ} 19^{\prime} \mathrm{E}$ ) to Port-Said (in the east Long. $31^{\circ} 19^{\prime} \mathrm{E}$ ) with a length of about $180 \mathrm{~km}$, and with a width in a N-S direction for about $15 \mathrm{~km}$ from the coast, which covers the north borders of three Governorates namely: Damietta, El-Dakahlia and Kafr El-Sheikh. Ecologically, the study area comprises four habitats: salt marshes, sand formations, reed swamps and fertile non-cultivated lands habitat [18].

Geologically, the Nile Delta, as a part of northern Egypt, has been subjected to the same geologic events that affected the whole region during its geological history. The formation of the Nile Delta started in the late Pliocene with its main development in the Pleistocene and Holocene associated with progradation of large volumes of coastal Delta sands and the accumulation of turbidities off shore (Nile cone) [19].

The soils of the Nile Delta are heavy in texture, rather compact at the surface and rich in humus [20]. According to the map of the world distribution of the arid regions
[21], soil of the study area are man-made variants of Gley soils and Fluvisoils that belong to the Pliocene and Pleistocene [22]. Deposits covering the Delta reach about $10.9 \mathrm{~m}$ in thickness. These deposits are composed mainly of silt, clay, sandy clay with biotite, magnetite and limestone formations, these deposits are considered as the basis of Egypt's fertility [23].

\subsection{Plant Sampling and Analyses}

In the study area, wild plant species $(n=6)$ were collected at full maturity stage during March to June 2017, marked properly and packed in polyethylene bags. Nomenclature and identification of plant species were carried out according to Tackholm [24] and Boulos [25] (Table 1). All plants were washed and cleaned with tape water, separated into roots and shoots, oven dried at $50{ }^{\circ} \mathrm{C}$, and ground into powder with electric grinder. For metal analyses, $0.1 \mathrm{~g}$ (dry weight) of plant samples was added to Teflon beakers and digested with $\mathrm{HNO}_{3} / \mathrm{H}_{2} \mathrm{O}_{2}(3: 1, \mathrm{v} / \mathrm{v})$ at 70 to $90^{\circ} \mathrm{C}$ during which temperatures were raised to approximately $95^{\circ} \mathrm{C}$ until evolution of nitrous gas had stopped and the digest became quite clear. The digests were diluted with distilled water up to a known volume [26]. Fe, Cd, Co, $\mathrm{Ni}$ and $\mathrm{Pb}$ were estimated using Atomic Absorption Spectrometer (A Perkin-Elemer, Model 2380, USA).

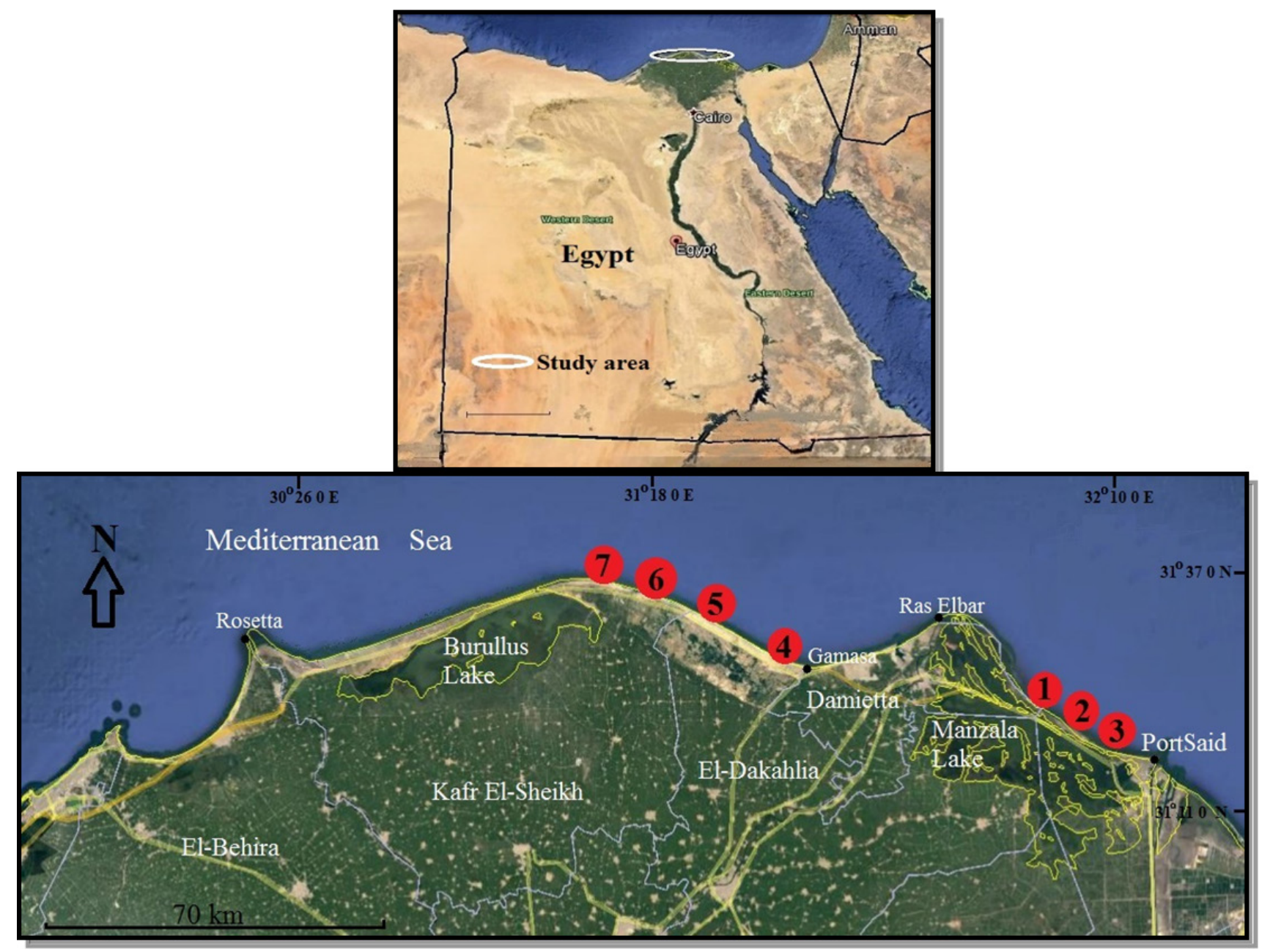

Figure 1. A map showing study area and the sampling sites 
Table 1. List of native plant species and their respective families

\begin{tabular}{|c|c|c|c|c|}
\hline Scientific name & Vernacular name & Family & Duration & Site collection \\
\hline Atriplex halimus L. & Qataf & Chenopodiaceae & Perennial & $4,5,6 \& 7$ \\
\hline Limoniastrum monopetalum (L.) Boiss. & Zeita & Plumbaginaceae & Perennial & $4,5,6 \& 7$ \\
\hline Limonium pruinosum (L.) Chaz. & Molleih & Plumbaginaceae & Perennial & $4,5,6 \& 7$ \\
\hline Suaeda maritima (L.) Dumort & Sowweid & Chenopodiaceae & Annual & $1,2 \& 3$ \\
\hline Suaeda pruinosa Lange & Sowweid & Chenopodiaceae & Perennial & $1,2 \& 3$ \\
\hline Zygophyllum aegyptium Hosny & Rotreit & Zygophyllaceae & Perennial & $4,5,6 \& 7$ \\
\hline
\end{tabular}

\subsection{Soil Sampling and Analyses}

Surface soil samples $(0-20 \mathrm{~cm}$ depth; $\mathrm{n}=6)$ were collected from each site (triplicates) using a Van-Veen grab coated with polyethylene. Soil texture and amount of organic matter were determined according to Piper [27], while calcium carbonate content was determined according to Jackson [28]. The soil solution (1:5) was prepared and electrical conductivity and $\mathrm{pH}$ values were determined by portable meter (Model Corning, NY 14831 USA) [28]. To detect the heavy metal contamination in the sediment samples. The samples were deep-frozen until analysis. The samples were dried in the oven at $70^{\circ} \mathrm{C}$ and sieved using $0.75 \mathrm{~mm}$ plastic sieve and digested for about two hours in a mixture of 3:2:1 $\mathrm{HNO}_{3}, \mathrm{HCLO}_{4}$ and $\mathrm{HF}$ acids, respectively as described by Oregioni and Astone [29].

\subsection{Pollution Quantification}

The pollution quantification for each metal were calculated by determination of Contamination Factor (CF), Enrichment Factor (EF) and Pollution Load Index (PLI) using the following equations according to Shah et al. [30] and Muhammad et al. [31]:

$$
\text { Contamination factor }(C F)=\frac{C_{m \text { sample }}}{C_{m \text { background }}}
$$

Where $C_{m}$ represents the concentrations of metals in contaminated and background sites.

Enrichment Factor is considered as an effective tool to evaluate the magnitude of contaminants in the environment. Iron $(\mathrm{Fe})$ was chosen as the controlling element [32].

$$
\text { (Enrichment factor) } E F=\frac{C_{\text {trace metal }}}{C_{\text {background }}}
$$

Where, $C$ is the concentration of metal.

$$
\begin{aligned}
& \text { (Pollution load index)PLI } \\
& =n \sqrt{C F 1 \times C F 2 \times C F 3 \ldots \ldots \ldots \ldots \ldots C F n}
\end{aligned}
$$

Where $n$ is the number of metals (five in the present study) and $\mathrm{CF}$ is the contamination factor value.

\subsection{Phytoremediation Efficiency}

The translocation factor (TF) and bioaccumulation factor (BAF) were calculated for heavy metals. TF is the translocation of a metal from the roots to shoots. However, BAF determines the ability of a plant to uptake a metal from soils. In this study, the TF and BAF values for heavy metals are calculated with the following equations:

$$
\begin{gathered}
T F=\frac{C_{\text {shoot }}}{C_{\text {root }}} \\
B A F_{\text {shoot }}=\frac{C_{\text {shoot }}}{C_{\text {soil }}} \\
B A F_{\text {root }}=\frac{C_{\text {root }}}{C_{\text {soil }}}
\end{gathered}
$$

Where $C_{\text {shoot }}, C_{\text {root }}$, and $C_{\text {soil }}$ represent the metal concentrations in the shoots, roots, and soil, respectively $[33,34]$.

\subsection{Statistical Analyses}

The analysis of soil samples and heavy metal of plant were done in triplicates and the data is presented as mean \pm standard deviation. Pearson correlation coefficients were calculated to analyze the correlation between heavy metals in plant and soil.

\section{Results and Discussion}

\subsection{Soil}

\subsubsection{Physiochemical Parameters}

The heavy metal contents in soil are also dependent on soil physico-chemical properties, which affect the mobility, availability and ecotoxicological risks of heavy metals [35]. Table 2 summarizes the physico-chemical properties of the soil. Soil $\mathrm{pH}$ mean values were found highest in site 1 (9.86), while they were lowest in site 4 (7.81) of the study area. Soil conductivity which indicates the salinity was maximum at site $3\left(4.73 \mathrm{~ms}^{-\mathrm{cm}^{-1}}\right)$ and minimum at site $6\left(0.47 \mathrm{~ms}^{-\mathrm{cm}^{-1}}\right)$. The $\mathrm{pH}$ changed among the studied sites as a result of different drainage waters and soil organic matter, highest EC values were recorded at site 1,2, 3 and 7 due to nearby lakes and sea water intrusion from the Mediterranean Sea [36].

The observed soils were found to be sandy in texture with sand contents ranging from 77.4 (Site 2) to $96.8 \%$ (Site 6). Similarly, SOM was found highest in site 2 $(1.97 \%)$, while it was lowest in site $6(0.43 \%)$ (Table 2$)$. The soil organic matter (SOM) associated with different soil textures (sand, silt, and clay) and will differ in susceptibility to decomposition, which is one of the most important indicators of soil health (Rattan et al. 2005). The main reason for such low levels of SOM is the poor silt and clay contents of soils [37]. The carbonate content $\left(\mathrm{CaCO}_{3}\right)$ ranged from 1.89 to $5.95 \%$ revealing the nature 
of the studied soils, which play role in soil structure, colour and neutralize soil acidity. The levels of soil physico-chemical parameters in the present study were similar to the levels observed in other study $[38,39,40]$.

Table 2. Soil analysis collected from the Deltaic Mediterranean coast during winter (2017)

\begin{tabular}{|c|c|c|c|c|c|c|c|c|}
\hline \multirow{2}{*}{ Soil parameters } & \multicolumn{7}{|c|}{ Sites no. } & \multirow{2}{*}{ Mean } \\
\hline & 1 & 2 & 3 & 4 & 5 & 6 & 7 & \\
\hline $\mathrm{pH}$ & $9.86 \pm 0.93$ & $9.12 \pm 0.85$ & $8.05 \pm 0.75$ & $7.81 \pm 0.72$ & $8.3 \pm 0.77$ & $8.54 \pm 0.80$ & $8.01 \pm 0.74$ & $8.53 \pm 0.80$ \\
\hline EC ms.cm ${ }^{-1}$ & $1.79 \pm 0.12$ & $3.79 \pm 0.32$ & $4.73 \pm 0.42$ & $0.84 \pm 0.03$ & $0.48 \pm 0.05$ & $0.47 \pm 0.05$ & $1.09 \pm 0.04$ & $1.88 \pm 0.13$ \\
\hline Sand \% & $90.2 \pm 8.96$ & $77.4 \pm 7.68$ & $83.3 \pm 8.27$ & $92.6 \pm 9.60$ & $94.7 \pm 9.61$ & $96.8 \pm 9.59$ & $91.2 \pm 9.62$ & $89.46 \pm 7.05$ \\
\hline Silt \% & $6.7 \pm 0.61$ & $12.4 \pm 1.18$ & $9.4 \pm 0.88$ & $2.3 \pm 0.17$ & $2.6 \pm 0.020$ & $1.6 \pm 0.10$ & $1.2 \pm 0.06$ & $5.17 \pm 0.64$ \\
\hline Clay \% & $3.1 \pm 0.25$ & $10.2 \pm 0.96$ & $7.3 \pm 0.67$ & $1.1 \pm 0.05$ & $0.7 \pm 0.01$ & $1.9 \pm 0.13$ & $2 \pm 0.14$ & $3.76 \pm 0.32$ \\
\hline $\mathrm{CaCO} 3 \%$ & $5.89 \pm 0.53$ & $5.95 \pm 0.54$ & $5.24 \pm 0.47$ & $3.29 \pm 0.27$ & $3.12 \pm 0.25$ & $1.89 \pm 0.13$ & $3.18 \pm 0.26$ & $4.08 \pm 0.31$ \\
\hline SOM \% & $1.79 \pm 0.05$ & $1.97 \pm 0.06$ & $1.72 \pm 0.04$ & $0.46 \pm 0.03$ & $0.48 \pm 0.03$ & $0.43 \pm 0.02$ & $0.45 \pm 0.02$ & $1.04 \pm 0.04$ \\
\hline
\end{tabular}

EC: Electrical conductivity; SOM: Soil organic matter.

Table 3. Total metals concentration ( $\mu \mathrm{gg}^{-1} \mathrm{dry}$ weight) in soil from the Deltaic Mediterranean coast during winter (2017)

\begin{tabular}{|c|c|c|c|c|c|}
\hline \multirow{2}{*}{ Sites no. } & \multicolumn{5}{|c|}{ Metals ( $\mu g^{-1}$ dry weight) } \\
\hline & $\mathrm{Fe}$ & $\mathrm{Pb}$ & $\mathrm{Ni}$ & $\mathrm{Co}$ & $\mathrm{Cd}$ \\
\hline 1 & $2002.36 \pm 20.0$ & $18.4 \pm 1.8$ & $62.25 \pm 6.2$ & $20.54 \pm 2.1$ & $2 \pm 0.2$ \\
\hline 2 & $1940.96 \pm 19.4$ & $20.2 \pm 2.0$ & $42.4 \pm 4.2$ & $17.4 \pm 1.7$ & $1.8 \pm 0.1$ \\
\hline 3 & $2043.96 \pm 20.6$ & $22.8 \pm 2.3$ & $49.21 \pm 4.9$ & $13.64 \pm 1.4$ & $2.3 \pm 0.2$ \\
\hline 4 & $760.96 \pm 7.6$ & $5.41 \pm 0.5$ & $3.65 \pm 0.4$ & $0.53 \pm 0.1$ & $0.9 \pm 0.2$ \\
\hline 5 & $789.56 \pm 7.9$ & $8.47 \pm 0.8$ & $7.45 \pm 0.7$ & $1.54 \pm 0.2$ & $1.1 \pm 0.2$ \\
\hline 6 & $1079.56 \pm 10.8$ & $3.24 \pm 0.3$ & $4.65 \pm 0.5$ & $2.98 \pm 0.3$ & $0.7 \pm 0.1$ \\
\hline 7 & $1811.76 \pm 18.1$ & $9.48 \pm 0.9$ & $25.64 \pm 2.6$ & $7.54 \pm 0.8$ & $1.2 \pm 0.1$ \\
\hline Mean & $1489.87 \pm 14.9$ & $12.57 \pm 1.3$ & $27.89 \pm 2.8$ & $9.17 \pm 0.9$ & $1.43 \pm 0.1$ \\
\hline Average shale & 47200 & 20 & 68 & 19 & 0.3 \\
\hline EPA, 2002 & 15 & 10 & - & - & 6 \\
\hline EU, 2002 & - & 300 & 75 & 11.6 & 3 \\
\hline
\end{tabular}

Average shale, after Turekian and Wedepohl [41]

EPA: Environmental Protection Agency for sediment samples in $(\mu \mathrm{g} / \mathrm{g})$.

EU: European Union Standard in $(\mu \mathrm{g} / \mathrm{g})$.

\subsubsection{Heavy Metal Contents in Soil}

Heavy metals concentration in soil samples from the seven sampling sites along are presented in Table 3 . The concentrations of different heavy metals displayed remarkable site to site variations, with the highest concentration recorded at the site 3 for most metals. Fe (760.96 - $2043.96 \mathrm{\mu gg}^{-1}$ dry weight) maintain relatively the highest concentration followed by $\mathrm{Ni}\left(3.65-62.25 \mu^{-1}\right.$ dry weight), $\mathrm{Pb}\left(3.24-22.8 \mu \mathrm{gg}^{-1}\right.$ dry weight $), \mathrm{Co}(0.53-$ $20.54 \mathrm{mgl}-1)$ and $\mathrm{Cd}(0.7-2.3 \mu \mathrm{gg}-1$ dry weight $)$. The concentrations of metals were observed in the order of $\mathrm{Fe}>\mathrm{Ni}>\mathrm{Pb}>\mathrm{Co}>\mathrm{Cd}$.

The main sources of heavy metals in the soil samples are parent rock material, polluted irrigation water, sea water intrusion and various agrochemicals (fertilizers, pesticides, weedicides etc.) [42,43]. Site 1, 2 and 3 demonstrated the highest level of heavy metal contamination recorded during the present study. This can be explained by the increasing industrial activities at these sites and sea water intrusion [44]. These results are in agreement with those obtained by El-Sikaily et al. [45] at other Egyptian coastal areas on the Mediterranean and Red Sea and El-Serehy et al. [44] at Deltaic Mediterranean coast. However, these concentrations were found higher than those reported by Beheary and El-Matary [46] in soil of northern Nile Delta. The heavy metal contents in soil samples in the present analysis are high the maximum permissible limits set by EPA [47] but within the limit of EU [48].

\subsubsection{Metal Enrichment Factor (EF)}

The Enrichment Factor (EF) in metals is indicator used to assess the presence and intensity of anthropogenic contaminant deposition on surface soil [49]. Figure 2 summarizes the soil EF values at studied sites in Deltaic Mediterranean coast. Cd (102.02-219.19) maintain relatively the highest concentration followed by $\mathrm{Pb}(7.08-26.33)$, $\mathrm{Co}(1.73-25.48)$ and $\mathrm{Ni}(2.99-21.58)$. Values of $0.5 \leq \mathrm{EF} \leq 1.5$ suggest that the trace metal concentration may come entirely from natural weathering processes [50]. However, an $\mathrm{EF}>1.5$ indicates that a significant portion of the trace metals was delivered from non- crustal materials so, these 
trace metals were delivered by other sources, like point and non-point pollution and biota [51,50]. According to categories proposed by Sutherland et al. [51] the deltaic coast has extremely high enrichment values for Cd; very high enrichment for $\mathrm{Pb}$ and $\mathrm{Co}$ and low enrichment values for $\mathrm{Ni}$ and $\mathrm{Fe}$.

\subsubsection{Contamination Factor (CF) and Contamination Degree (CD)}

The contamination factor of different heavy metals displayed remarkable site to site variations, with the highest concentration recorded at the site 3 for all metals (Figure 3). Cd (2.33-7.67) maintain relatively the highest concentration followed by $\mathrm{Pb}(0.16-1.14)$, Co (0.03-1.08), $\mathrm{Ni}(0.05-0.92)$ and $\mathrm{Fe}(0.02-0.04)$. According to Hakanson classification [52], $\mathrm{CF}<1$ (low contamination factor); $1 \leq$ $\mathrm{CF}<3$ (moderate contamination factors); $3 \leq \mathrm{CF}<6$ (considerable contamination factors) and $\mathrm{CF} \geq 6$ (very high contamination factor). On this basis, the deltaic coast has very high $\mathrm{CF}$ values for $\mathrm{Cd}$; moderate $\mathrm{CF}$ for $\mathrm{Pb}$ and $\mathrm{Co}$; low $\mathrm{CF}$ for $\mathrm{Ni}$ and $\mathrm{Fe}$. Calculation of the contamination degree $(\mathrm{CD})$ indicates that the deltaic coast is considered to be coast with low to moderate contamination degree [52], vary between 2.74 and 10.29 with mean value of 6.31 (Figure 4), indicating serious anthropogenic pollution.

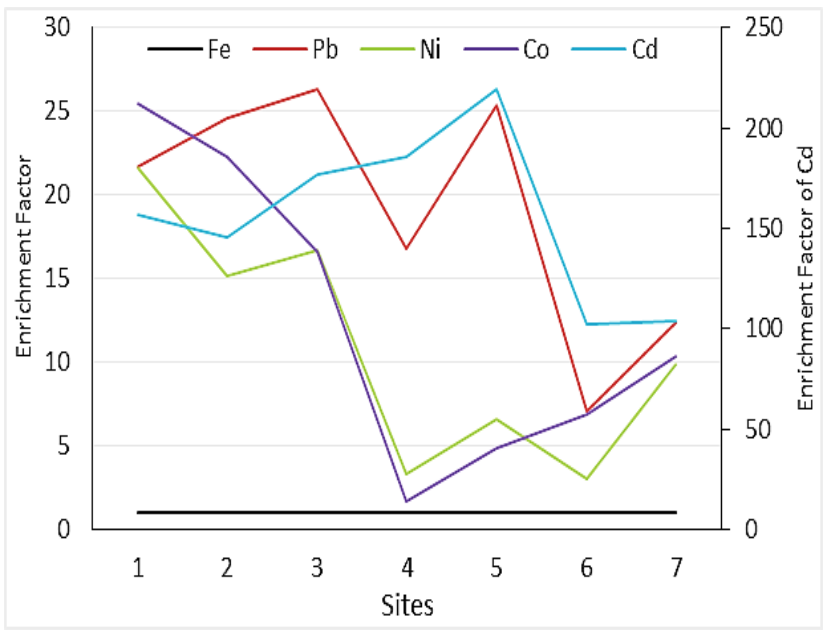

Figure 2. Enrichment factor value of soil in the study area

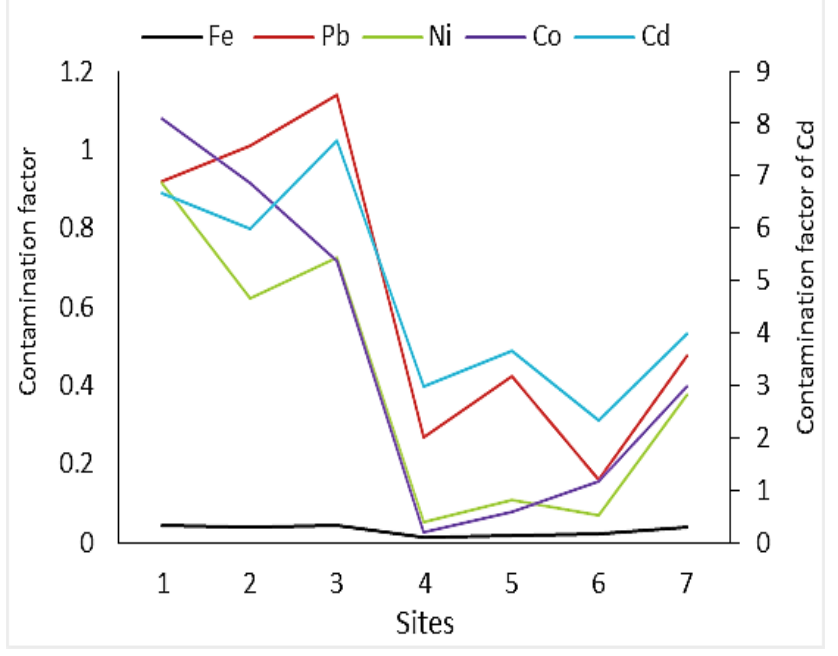

Figure 3. Contamination factor value of soil in the study area

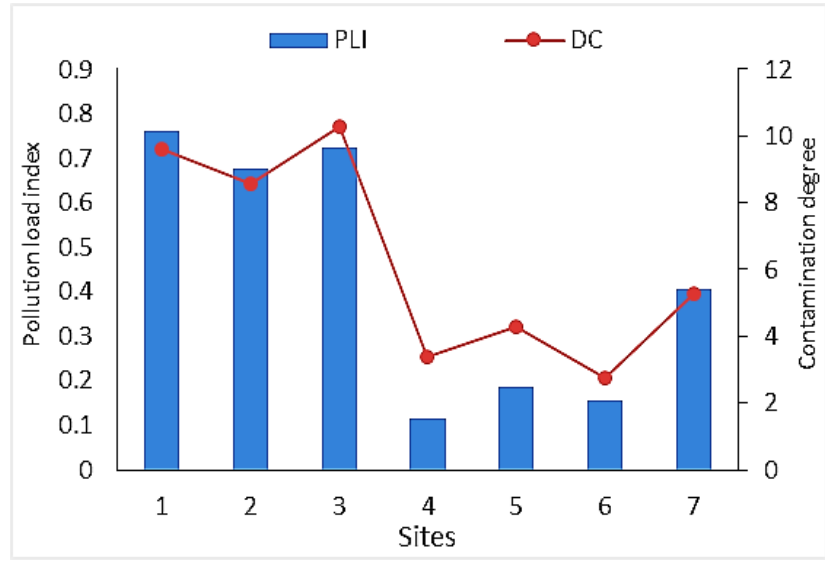

Figure 4. Contamination degree and pollution load index values of soil in the study area.

\subsubsection{Pollution Load Index (PLI)}

The PLI is aimed at providing a measure of the degree of overall contamination at a sampling site. Figure 4 shows results of the PLI for the five metals studied at deltaic coast, vary between 0.11 and 0.76 with the mean value of 0.43 . This values $(\mathrm{PLI}<1)$ showed that there is no appreciable pollution in deltaic coast with those metals [47].

\subsection{Plants}

\subsubsection{Heavy Metal Concentrations in Plants}

Plant helps a good tool for phytoremediation. Hyper-accumulation refers to the natural ability of certain plants to clean up soil, air, and water contaminated with hazardous chemicals [53]. The heavy metal concentration in the different tissues of various plant species growing naturally along the Deltaic Mediterranean coast was recorded during the study periods (Table 4). Iron concentrations ranged from 90.98 to $695.3 \mu \mathrm{g} . \mathrm{g}^{-1}$ in root with a highest concentration in S. maritima and lowest in Z. aegyptium, while ranged from 186.89 to $360.4 \mu \mathrm{g} . \mathrm{g}^{-1}$ in shoot of $S$. pruinosa and L. pruinosum, respectively (Table 4). Fe as an essential nutrient plays an important role in plant cell wall, photosynthesis process and protein [54]. Plants uptake $\mathrm{Fe}$ through their roots at high concentrations and the produced free radicals permanently impair cellular structure and damage the membranes, DNA, and proteins [55].

The highest $\mathrm{Pb}$ concentration $\left(5.76\right.$ and $\left.5.11 \mu \mathrm{g} \cdot \mathrm{g}^{-1}\right)$ was observed in root of $Z$. aegyptium and in shoot of Suaeda pruinosa, respectively, while the lowest (root: 1.56 and shoot: $2.22 \mu \mathrm{g} . \mathrm{g}^{-1}$ ) was observed in S. maritima (Table 4). Generally, the $\mathrm{Pb}$ concentrations ranging from 1.56 to $5.11 \mu \mathrm{g} . \mathrm{g}^{-1}$, while safe agriculture limit is $10 \mu \mathrm{g} . \mathrm{g}^{-1}$ [56]. Pb is non-essential and toxic metal which causing phytotoxicity when exceeded the limits $[57,58]$.

The highest $\mathrm{Ni}$ concentration ranged from 2.21 to $3.58 \mu \mathrm{g} . \mathrm{g}^{-1}$ in root of Z. aegyptium and S. pruinosa, while ranged from 0.74 to $1.9 \mu \mathrm{g} . \mathrm{g}^{-1}$ in shoot of $S$. maritia and L. pruinosum, respectively. Nickel is an essential micronutrient that occurs in the environment at very small amounts as reported by Wood et al. [59]. Excess accumulation of Ni reduced the water content in plant species. This decrease in water uptake is used as an indicator of Ni toxicity in plants [60]. Similarity, cobalt concentration (1.11 - $\left.1.9 \mu \mathrm{g} \cdot \mathrm{g}^{-1}\right)$ 
was observed in root of Z. aegyptium and S. pruinosa, while in shoot $\left(0.5-1.0 \mu \mathrm{g} . \mathrm{g}^{-1}\right)$ was observed in $S$. maritia and L. pruinosum, respectively (Table 4 ). Plants can uptake only small amount of Co from the soil and its consequent distribution in plants is reliant on species mechanisms [61].

The highest concentrations of Cd (root: 0.13 to $2.4 \mu \mathrm{g} . \mathrm{g}^{-1}$; shoot: $0.08-1.8 \mu \mathrm{g} . \mathrm{g}^{-1}$ ) was observed in Atriplex halimus and Zygophyllum aegyptium, respectively. Cadmium is present as an impurity in some products, including phosphate fertilizers, detergents and refined petroleum products [62]. In plants, $\mathrm{Cd}$ accumulation causes growth inhibition, browning of root tips, chlorosis, water and nutrient uptake, reduction in photosynthesis and finally death [63].

\subsubsection{Metal Bioaccumulation Factor (BAF)}

Table 5 represents the bioaccumulation of roots, shoots, and transfer factor values in selected plant species collected from deltaic coast. The BAF was used to assess the capacity of studied plants to uptake metals from the surrounding environment. Plant species show TF and BAF greater than one are suitable for phytoextraction of heavy metals [64]. Among the plant species, the highest BAF shoot and root values (1.85 and 2.46) was observed in Atriplex halimus, while the lowest (0.01 and 0.05) was for Suaeda maritima, respectively. Similarly, the highest TF values (2.62, 1.73 and 1.58) were observed for $Z$. aegyptium, $S$. pruinosa and L. monopetalum, respectively, while the lowest $(0.26)$ was for $S$. pruinosa (Table 5).

Table 4. Mean concentration ( $\mu \mathrm{g} . \mathrm{g}^{-1}$ dry weight) of total heavy metals \pm standard deviation in tissues of studied halophytes during winter (2017)

\begin{tabular}{|l|c|c|c|c|c|c|}
\hline \multirow{2}{*}{ Plant species } & \multirow{2}{*}{ Plant part } & \multicolumn{5}{|c|}{ Metals $\left(\mu \mathrm{g} . \mathrm{g}^{-1}\right.$ dry weight $)$} \\
\cline { 2 - 7 } & & $\mathrm{Fe}$ & $\mathrm{Pb}$ & $\mathrm{Ni}$ & $\mathrm{Co}$ & $\mathrm{Cd}$ \\
\hline \multirow{3}{*}{ Atriplex halimus } & Shoot & $283.5 \pm 28.4$ & $4.35 \pm 0.4$ & $1.5 \pm 0.2$ & $0.8 \pm 0.1$ & $1.8 \pm 0.2$ \\
\cline { 2 - 7 } & Root & $458.69 \pm 45.9$ & $3.2 \pm 0.3$ & $2.67 \pm 0.3$ & $1.48 \pm 0.1$ & $2.4 \pm 0.2$ \\
\hline \multirow{3}{*}{ Limoniastrum monopetalum } & Shoot & $290.1 \pm 29.1$ & $4.3 \pm 0.4$ & $1.7 \pm 0.2$ & $0.9 \pm 0.1$ & $0.6 \pm 0.1$ \\
\cline { 2 - 7 } & Root & $311.45 \pm 31.1$ & $2.48 \pm 0.2$ & $2.89 \pm 0.3$ & $1.24 \pm 0.1$ & $0.9 \pm 0.1$ \\
\hline \multirow{3}{*}{ Limonium pruinosum } & Shoot & $360.4 \pm 36.0$ & $5.0 \pm 0.5$ & $1.9 \pm 0.2$ & $1.0 \pm 0.1$ & $0.8 \pm 0.1$ \\
\cline { 2 - 7 } & Root & $476.2 \pm 47.6$ & $3.15 \pm 0.3$ & $3.42 \pm 0.3$ & $1.56 \pm 0.2$ & $1.78 \pm 0.2$ \\
\hline \multirow{3}{*}{ Suacda maritima } & Shoot & $234.36 \pm 23.4$ & $2.22 \pm 0.2$ & $0.74 \pm 0.1$ & $0.5 \pm 0.1$ & $0.81 \pm 0.1$ \\
\cline { 2 - 7 } & Root & $695.3 \pm 69.5$ & $1.56 \pm 0.2$ & $2.59 \pm 0.3$ & $1.12 \pm 0.2$ & $1.41 \pm 0.1$ \\
\hline \multirow{2}{*}{ Zygophyllum aegyptium } & Shoot & $186.89 \pm 18.7$ & $5.11 \pm 0.5$ & $1.59 \pm 0.2$ & $0.8 \pm 0.1$ & $0.82 \pm 0.1$ \\
\cline { 2 - 7 } & Root & $636.14 \pm 63.6$ & $3.23 \pm 0.3$ & $3.58 \pm 0.4$ & $1.9 \pm 0.1$ & $2.34 \pm 0.2$ \\
\cline { 2 - 7 } & Shoot & $238.45 \pm 23.8$ & $4.09 \pm 0.4$ & $1.54 \pm 0.2$ & $0.85 \pm 0.1$ & $0.08 \pm 0.0$ \\
\cline { 2 - 7 } & Root & $90.98 \pm 9.1$ & $5.76 \pm 0.6$ & $2.21 \pm 0.2$ & $1.11 \pm 0.1$ & $0.13 \pm 0.0$ \\
\hline
\end{tabular}

Table 5. Bioaccumulation of metals in roots, shoots, and their transfer factors in contaminated sites

\begin{tabular}{|c|c|c|c|c|c|c|}
\hline \multirow{2}{*}{ Plant species } & \multirow{2}{*}{ Plant part } & \multicolumn{5}{|c|}{ Metals } \\
\hline & & $\mathrm{Fe}$ & $\mathrm{Pb}$ & $\mathrm{Ni}$ & Co & $\mathrm{Cd}$ \\
\hline \multirow{3}{*}{ Atriplex halimus } & BAF $_{\text {Root }}$ & 0.41 & 0.48 & 0.26 & 0.47 & 2.46 \\
\hline & $\mathrm{BAF}_{\text {Shoot }}$ & 0.26 & 0.65 & 0.14 & 0.25 & 1.85 \\
\hline & $\mathrm{TF}$ & 0.62 & 1.36 & 0.56 & 0.54 & 0.75 \\
\hline \multirow{3}{*}{ Limoniastrum monopetalum } & BAF $_{\text {Root }}$ & 0.28 & 0.37 & 0.28 & 0.39 & 0.92 \\
\hline & $\mathrm{BAF}_{\text {Shoot }}$ & 0.26 & 0.65 & 0.16 & 0.29 & 0.62 \\
\hline & $\mathrm{TF}$ & 0.93 & 1.73 & 0.59 & 0.73 & 0.67 \\
\hline \multirow{3}{*}{ Limonium pruinosum } & BAF $_{\text {Root }}$ & 0.43 & 0.47 & 0.33 & 0.50 & 1.83 \\
\hline & $\mathrm{BAF}_{\text {Shoot }}$ & 0.32 & 0.75 & 0.18 & 0.32 & 0.82 \\
\hline & TF & 0.76 & 1.59 & 0.56 & 0.64 & 0.45 \\
\hline \multirow{3}{*}{ Suaeda maritima } & BAF $_{\text {Root }}$ & 0.35 & 0.08 & 0.05 & 0.11 & 0.69 \\
\hline & $\mathrm{BAF}_{\text {Shoot }}$ & 0.12 & 0.11 & 0.01 & 0.03 & 0.40 \\
\hline & TF & 0.34 & 1.42 & 0.29 & 0.26 & 0.57 \\
\hline \multirow{3}{*}{ Suaeda pruinosa } & BAF $_{\text {Root }}$ & 0.32 & 0.16 & 0.07 & 0.07 & 1.15 \\
\hline & $\mathrm{BAF}_{\text {Shoot }}$ & 0.09 & 0.25 & 0.03 & 0.05 & 0.40 \\
\hline & $\mathrm{TF}$ & 0.29 & 1.58 & 0.44 & 0.71 & 0.35 \\
\hline \multirow{3}{*}{ Zygophyllum aegyptium } & BAF $_{\text {Root }}$ & 0.08 & 0.87 & 0.21 & 0.35 & 0.14 \\
\hline & $\mathrm{BAF}_{\text {Shoot }}$ & 0.21 & 0.62 & 0.15 & 0.27 & 0.08 \\
\hline & $\mathrm{TF}$ & 2.62 & 0.71 & 0.69 & 0.76 & 0.59 \\
\hline
\end{tabular}


In the study area, most plant species had a $\mathrm{TF}<1$ for $\mathrm{Fe}$, $\mathrm{Ni}, \mathrm{Co}$ and $\mathrm{Cd}$ except $\mathrm{Pb}$ greater than one, while the $\mathrm{BAF}$ values for $\mathrm{Fe}, \mathrm{Pb}, \mathrm{Ni}$, $\mathrm{Co}$ and $\mathrm{Cd}$ were $<1$, except $\mathrm{BAF}$ root of $A$. halimus, L. pruinosum and $S$. pruinosa were $>1$. Phytoextraction usually involves the uptake of toxic heavy metals from contaminated soils and their accumulation in harvestable parts of plant species. Plants being considered as hyperaccumulators must have the potential to tolerate the metals and transfer them from roots to above-ground parts of the plant species [65]. On the basis of the BAF values, only $A$. halimus could be considered as a $\mathrm{Cd}$ hyperaccumulator as this species had a BAF shoot and root values $>1$. On the basis of $\mathrm{TF}, Z$. aegyptium for $\mathrm{Fe}$ and all plant species could be considered as hyperaccumulators for $\mathrm{Pb}$ except $Z$. aegyptium. Generally, different plant species showed a variation in metal accumulation and uptake. This may be due to different concentrations of the metals in soil, $\mathrm{pH}$, soil organic matter [9], age of plant, and plant physiology.

The uptake of metals by halophytic plants depends upon their mobility and availability in sediments. In the view of the above-mentioned data, metals in halophytes are mainly accumulated in the roots with small quantities translocated to the stems and leaves, except in the case of more mobile elements such as $\mathrm{Mn}, \mathrm{Cd}$ and $\mathrm{Zn}$ [17].

Table 6. Inter-correlations between the heavy metals in soil, roots, and shoots of the plant species

\begin{tabular}{|c|c|c|c|c|c|}
\hline & $\mathrm{Fe}$ & $\mathrm{Pb}$ & $\mathrm{Ni}$ & Co & $\mathrm{Cd}$ \\
\hline \multicolumn{6}{|c|}{ Soil } \\
\hline $\mathrm{Fe}$ & 1.000 & $0.842 *$ & $0.916^{* *}$ & $0.903 * *$ & $0.838^{*}$ \\
\hline $\mathrm{Pb}$ & & 1.000 & $0.912 * *$ & $0.880 * *$ & $0.984 * *$ \\
\hline $\mathrm{Ni}$ & & & 1.000 & $0.971 * *$ & $0.933 * *$ \\
\hline $\mathrm{Co}$ & & & & 1.000 & $0.868 *$ \\
\hline $\mathrm{Cd}$ & & & & & 1.000 \\
\hline \multicolumn{6}{|c|}{ Shoots } \\
\hline $\mathrm{Fe}$ & 1.000 & 0.239 & 0.494 & 0.588 & 0.184 \\
\hline $\mathrm{Pb}$ & & 1.000 & $0.930 * *$ & $0.866^{*}$ & 0.072 \\
\hline $\mathrm{Ni}$ & & & 1.000 & $0.988 * *$ & -0.064 \\
\hline $\mathrm{Co}$ & & & & 1.000 & -0.12 \\
\hline $\mathrm{Cd}$ & & & & & 1.000 \\
\hline \multicolumn{6}{|c|}{ Roots } \\
\hline $\mathrm{Fe}$ & 1.000 & -0.789 & 0.541 & 0.596 & 0.749 \\
\hline $\mathrm{Pb}$ & & 1.000 & -0.344 & -0.684 & -0.475 \\
\hline $\mathrm{Ni}$ & & & 1.000 & -0.099 & 0.652 \\
\hline $\mathrm{Co}$ & & & & 1.000 & 0.245 \\
\hline $\mathrm{Cd}$ & & & & & 1.000 \\
\hline
\end{tabular}

*: Values are significant at $\mathrm{P}<0.05$;

**: Values are significant at $\mathrm{P}<0.01$.

\subsubsection{Inter-Metals Correlations in Plants and Soil}

The simple linear correlation coefficient showed a strong significant correlation between pairs of heavy metals in all soil samples $(\mathrm{P}<0.05$ and $\mathrm{P}<0.01$ ) (Table 6). Similarly, a correlation was also observed in shoots for $\mathrm{Pb}-\mathrm{Ni}(\mathrm{r}=0.930)$, $\mathrm{Ni}-\mathrm{Co}(\mathrm{r}=0.988)$ and $\mathrm{Co}-\mathrm{Pb}(\mathrm{r}=0.866)$, while in roots negative or no correlations between the pairs of heavy metals (Table 6). A correlation gives us knowledge about heavy metal sources and pathways. These results showed that the selected metals derived from the same polluting source in the study area (Deltaic Mediterranean coast) were both anthropogenic and geogenic (weathering of bed rocks) [66].

\section{Conclusion}

In the present study, we have concluded that:

1) The heavy metal contents in soil are also dependent on soil physico-chemical properties, the concentrations of different heavy metals in soils have the sequence of $\mathrm{Fe}>\mathrm{Ni}>\mathrm{Pb}>\mathrm{Co}>\mathrm{Cd}$.

2) The pollution quantification for each metal in the study area indicated that, the extremely high enrichment value for $\mathrm{Cd}$; very high enrichment values for $\mathrm{Pb}$ and $\mathrm{Co}$ and low enrichment values for $\mathrm{Ni}$ and Fe; The contamination factor has very high for $\mathrm{Cd}$; moderate for $\mathrm{Pb}$ and $\mathrm{Co}$ and low for $\mathrm{Ni}$ and $\mathrm{Fe}$, while the contamination degree (CD) indicates that the study area is considered to be coast with low to moderate contamination degree (2.74 and 10.29).

3) In the study area, the concentrations of heavy metals in plant species have the order of $\mathrm{Fe}>\mathrm{Pb}>\mathrm{Ni}$ $>\mathrm{Cd}>\mathrm{Co}$. most plant species had a $\mathrm{TF}<1$ for $\mathrm{Fe}, \mathrm{Ni}$, $\mathrm{Co}$ and $\mathrm{Cd}$ except $\mathrm{Pb}>1$, while the BAF values for $\mathrm{Fe}, \mathrm{Pb}, \mathrm{Ni}, \mathrm{Co}$ and $\mathrm{Cd}$ were $<1$, except BAF root of A. halimus, L. pruinosum and S. pruinosa were $>1$.

4) The highest BAF shoot and root values was observed in Atriplex halimus, while the lowest was for Suaeda maritima. Similarly, the highest TF values were observed for Z. aegyptium, S. pruinosa and L. monopetalum, while the lowest was for $S$. pruinosa.

5) The Potential environmental dangers are related with large amounts of heavy metals in soils and plant species. The current research demonstrated that some plant species could be appropriate for remediation of contaminated sites.

\section{Acknowledgments}

The authors gratefully acknowledge to Dr. Muhammad A. El-Alfy, Marine Pollution Department, National Institute of Oceanography and Fisheries, Egypt for the calculating the soil indices and revising the manuscript.

\section{List of Abbreviations}

EC: Electrical Conductivity

SOM: Soil Organic Matter

EPA: Environmental Protection Agency for sediment samples in $(\mu \mathrm{g} / \mathrm{g})$

EU: European Union Standard in $(\mu \mathrm{g} / \mathrm{g})$

BAF: Bioaccumulation Factor

TF: Translocation Factor

EF: Enrichment Factor

CF: Contamination factor

CD: Contamination Degree

PLI: Pollution Load Index. 


\section{References}

[1] Isola, E.F.; Olatunji, O.A.; Afolabi, A.M. and Omodara, A.A 2015. Heavy metal accumulation in the above-ground vegetation and soil around an iron smelting factory in Ile-Ife, southwestern Nigeria. Sciences in Cold and Arid Regions. 7(2): 121-127.

[2] Rattan, R.K.; Datta, S.P.; Chhonkar, P.K.; Suribabu, K. and Singh, A.K. 2005. Long-term impact of irrigation with sewage effluents on heavy metal content in soils, crops and groundwater: a case study. Agriculture Ecosystem Environmental. 109: 310-322.

[3] Kulha, A.; Sheorayan, A.; Bajar, S.; Sarkar, S.; Chaudhury, A. and Kalia, R.K. 2013. Investigation of heavy metals in frequently utilized medicinal plants collected from environmentally diverse locations of north western India. Springerplus 2: 676-687.

[4] Ahmad, K.; Ibrahim, M.; Khan, Z.I.; Rizwan, Y.; Ejaz, A.; Fardsous, A.; Gondal, S.; Lee, D.J. and Al-Yemeni, M. 2011 Effect of sewage water on mineral nutritive potential of six fodder species grown under semiarid conditions. Saudi Journal of Biological Science. 18: 317-321.

[5] Endalamaw, F.D. and Chandravanshi, B.S. 2015. Levels of major and trace elements in fenel (Foeniculum vulgari Mill.) fruits cultivated in Ethiopia. Springerplus 4: 5-15.

[6] Ali, H.; Naseer, M. and Sajad, M.A. 2012. Phytoremediation of heavy metals by Trifolium alexandrinum. International Journal of Environmental Science 2(3): 1459-1469.

[7] Jolly, Y.; Islam, A. and Akbar, S. 2013. Transfer of metals from soil to vegetables and possible health risk assessment. Springerplus 2: 385-393.

[8] Rajaganpathy, V.; Xavier, F.; Sreekumar, D. and Mandal, P.K. 2011. Heavy metal contamination in soil, water and fodder and their presence in livestock and products: a review. Journal Environmental Science and Technology. 4(3): 234-249.

[9] Khan, A.; Khan, S.; Khan, M.A.; Qamar, Z. and Waqas, M. 2015 The uptake and bioaccumulation of heavy metals by food plants, their effects on plants nutrients, and associated health risk: a review. Environmental Science and Pollution Research 22: 13772-13799.

[10] Paz-Alberto, A.M. and Sigua G.C. 2013. Phytoremediation: A Green Technology to Remove Environmental Pollutants. American Journal of Climate Change. 2: 71-86.

[11] Dutta, K. and Ghosh, A.R. 2016. Comparative study on bioaccumulation and translocation of heavy metals in some native plant species along the bank of chromite contaminated Damsal Nala of Sukinda Valley, Odisha, India. International Research Journal of Biological Sciences. 5(7): 32-52.

[12] Adewole, M.B. and Uchegbu, L.U. 2010. Properties of soils and plants uptake within the vicinity of selected Automobile workshops in Ile-Ife Southwestern, Nigeria. Ethiopian Journal of Environmental Studies and Management. 3(3): 31-35.

[13] Okoro, A.C.; Chukwuma, G.O.; Chukwuma, E.C.; Nwachukwu, P.C. and Ezeh, K.A. 2013. Investigating the effects of selected heavy metals on topsoil at the vicinities of two automobile Mechanic Villages, Owerri Municipal, Nigeria. The International Journal of Engineering and Science. 2(11): 19-26.

[14] Baker, A.J.M. and Walker, P.L. 1989. Physiological responses of plants to heavy metals and the quantification of tolerance and toxicity, Chemical Speciation \& Bioavailability, 1(1): 7-17.

[15] Reeves, R.D. and Baker, A.J.M. 2000. Metal-accumulating plants. In: Phytoremediation of Toxic Metals [Raskin, I. and Ensley, B.D. (Editors)]. John Wiley, New York. 193-229.

[16] Wilfried, H.O.E. 2006. Evolution of metal tolerance in higher plants. Forests Snow Landscape Research. 80(3): 251-274.

[17] Reboreda, R. and Caçador, I. 2007. Halophyte vegetation influences in salt marsh retention capacity for heavy metals. Environmental Pollution. 146: 147-154.

[18] Zahran, M.A. and Willis, A.J. 2009. The Vegetation of Egypt. 2nd ed. Springer. Netherlands.

[19] Davis, R.A. 1985. Coastal Sedimentary Environments. 2nd ed. Springer-Verlag. 3: 51-96.

[20] El-Gabaly, M.M.; Gewaifel, I. M.; Hassan, M. N. and Rozanov, B.G. 1969a. Soil and soil regions of United Arab Republic. Research Bulletin, Alexandria University. 21: 1-28.

[21] UNESCO. 1977. Map of the world distribution of arid regions. MAB Technical Notes. 7 University Press, Liverpool.

[22] El-Gabaly, M.; Gewaifel, I. M.; Hassan, M. N. and Rozanov, G. 1969b. Soil map and land resources of the United Arab Republic. Research Bulletin. 22: 1-14.
[23] Abu Al-Izz, M. S. 1971. Landforms of Egypt. American University of Cairo Press. Dar Al-Maaref, Cairo.

[24] Täckholm, V. 1974. Students' Flora of Egypt. $2^{\text {nd. }}$ edn. Publ. Cairo University, Beirut, 888.

[25] Boulos, L. (1999 \& 2005). Flora of Egypt, vol. 1 \& 4. Al Hadara Publishing, Cairo, Egypt.

[26] Allen, S. E.; Grimshaw, H. M.; Parkinson, J. A.; Quarmby, C. and Roberts, J. D. 1974. Chemical Analysis of Ecological Materials. Blackwell Scientific Publications. Osney, Oxford, London.

[27] Piper, C. S. 1947. Soil and plant analysis. Intersience Publishers, Inc. New York.

[28] Jackson, M. L. 1962. Soil Chemical Analysis. International Institute for Tropical Agriculture (IITA). Manual Series No.1, 70.

[29] Oregioni, B. and Astone, S. 1984. The determination of selected trace metals in marine sediments by flameless/flame-atomic absorption spectrophotometry. IAEA Monaco Laboratory, Internal Report.

[30] Shah, M.T.; Begum, S. and Khan, S. 2010. Pedo and biogeochemical studies of Mafic and Ultramafic Rocks in the Mingora and Kabal Areas, Swat, Pakistan. Environmental Earth Sciences. 60: 1091-1102.

[31] Muhammad, S.; Shah, M.T. and Khan, S. 2011. Heavy metal concentrations in soil and wild plants growing around $\mathrm{Pb}-\mathrm{Zn}$ sulfide Terrain in the Kohistan Region, Northern Pakistan. Microchemical Journal 99(1): 67-75.

[32] Seshan, B. R. R.; Natesan, U. and Deepthi, K., 2010. Geochemical and statistical approach for evaluation of heavy metal pollution in core sediments in southeast coast of India. International Journal of Environmental Science and Technology 7 (2): 291-306.

[33] Ma, L.Q.; Komar, K.M.; Tu, C.; Zhang, W.; Cai, Y. and Kennelley, E. D. 2001. A fern that hyperaccumulates arsenic. Nature 409: 579-585.

[34] Yoon, J.; Cao, X.; Zhou, Q. and Ma, L. Q. 2006. Accumulation of $\mathrm{Pb}, \mathrm{Cu}$, and $\mathrm{Zn}$ in native plants growing on a contaminated Florida site. Science of the Total Environment 368: 456-464.

[35] Boluda, R.; Roca-Perez, L. and Marimon, L. 2011. Soil plate assay: an effective method to determine ecotoxicological risks. Chemosphere. 84: 1-8.

[36] Osman, A.G.M. and Kloas, W. 2010. Water quality and heavy metal monitoring in water, sediments, and tissues of the African Catfish Clarias gariepinus (Burchell, 1822) from the River Nile, Egypt. Journal of Environmental Protection 1: 389-400.

[37] Sollins P, Homann P, Caldwell BA (1996) Stabilization and destabilization of soil organic matter: mechanisms and controls. Geoderma. 74(1): 65-105.

[38] Serag, M.S. 1999. Ecology of four succulent halophytes in the Mediterranean coast of Damietta Egypt. Estuarine, Coastal and Shelf Science. 49(1): 29-36.

[39] Hegazy, A.K.; Mussa, S.A.I. and Farrag, H.F. 2008. Invasive plant communities in the Nile Delta coast. Global Journal of Environmental Research. 2 (1): 53-61.

[40] Abd El-Gawad, A.M. and Shehata, H.S. 2014. Ecology and development of Mesembryanthemum crystallinum L. in the Deltaic Mediterranean coast of Egypt. Egyptian Journal of Basic and Applied Sciences. 1 (1): 29-37.

[41] Turekian, K.K. and Wedepohl, K.H. 1961. Distribution of the elements in some major units of the earth's crust. Geological Society of America Bulletin. 72(2): 175-192.

[42] Kaur, T.; Sharma, K. and Sinha, A.K. 2014. Industrial pollution in the sub-soil water and its health effects: a preliminary study around Buddha Nullah, Punjab. In: Sharma K, Sinha AK (eds) Human ecology in an era of globalization and urbanization. Serial Publications, New Delhi. 267-282.

[43] Bhatti, S.S.; Sambyal, V. and Nagpal, A.K. 2016. Heavy metals bioaccumulation in Berseem (Trifolium alexandrinum) cultivated in areas under intensive agriculture, Punjab, India. Springer Plus 5 : 173-184.

[44] El-Serehy, H.A.; Aboulela, H.; Al-Misned, F.; Kaiser, M.; AlRasheid, K. and Ezz El-Din, H. 2012. Heavy metals contamination of a Mediterranean Coastal Ecosystem, Eastern Nile Delta, Egypt. Turkish Journal of Fisheries and Aquatic Sciences. 12: 751-760.

[45] El-Sikaily, A.; Khaled, A. and El-Nemr, A. 2004. Heavy metals monitoring using bivalves from Mediterranean Sea and Red Sea. Environmental Monitoring and Assessment. 98 (1-3): 41-58.

[46] Beheary, M.S. and El-Matary F.A. 2016. Phytoaccumulation of heavy metals by two coastal halophytes. Journal of Environmental Sciences. 45(1): 85-94. 
[47] Environmental Protection Agency. 2002. National Recommended Water Quality Criteria. EPA, USA, 822-R-02-047.

[48] European Union, 2002. Heavy Metals in Wastes, European Commission on Environment. http://ec.europa.eu/environment/waste/studies/pdf/heavymetalsrep ort.pdf.

[49] Balls, P.W.; Hull, S.; Miller, B.S.; Pirie, J.M. and Proctor, W. 1997. Trace metal in Scottish estuarine and coastal sediments. Marine Pollution Bulletin. 34:42-50.

[50] Yongming, H.; Peixuan, D.; Junji, C. and Posmentier, E.S. 2006. Multivariate analysis of heavy metal contamination in urban dusts of Xi'an, Cent, China. Science of Total Environment. 355: 176-186.

[51] Sutherland, R.A.; Tolosa, C.A.; Tack, F.M.G. and Verloo, M.G. 2000. Characterization of selected element concentrations and enrichment ratios in background and anthropogenically impacted roadside areas. Archives of Environmental Contamination and Toxicology. 38: 428-438.

[52] Hakanson, L. 1980. An ecological risk index for aquatic pollution control: A sedimentological approach. Water Research, 14: 975-1001.

[53] Reichenauer, T.G. and Germida, J.J. 2008. Phytoremediation of organic contaminants in soil and groundwater. Chemsuschem. 1 (8-9): 708-17.

[54] Bell, R.W. and Dell, B. 2008. Micronutrients for sustainable food, feed, fibre and bioenergy production, IFA, Paris, France, 2008.

[55] DeDorlodot, S.; Lutts, S. and Bertin, P. 2005. Effects of ferrous iron toxicity on the growth and mineral composition of an interspecific rice. Journal of Plant Nutriation. 28: 1-20.

[56] Basta, N.T. and Gradwohl, R. 1998. Remediation of heavy metal contaminated soil using rock phosphate. Better Crops. 82(4): 29-31.
[57] Eun, S.O.; Youn, H.S. and Lee, Y. 2000. Lead disturbs microtubule organization in root meristem of Zea mays. Physiological Plantarum. 110: 357-365.

[58] McDermott, S.; Wu, J.; Cai, B.; Lawson, A. and Marjorie, A.C. 2011. Probability of intellectual disability is associated with soil concentrations of arsenic and lead. Chemosphere. 84(1): 31-38

[59] Wood, B.W.; Reilly, C.C. and Nyczepir, A.P. 2004. Mouse-ear of Pecan: a nickel deficiency. HortScience. 39(6): 1238-1242.

[60] Gajewska, E.; Sklodowska, M.; Slaba, M. and Mazur, J. 2006. Effect of nickel on antioxidative enzymes activities, proline and chlorophyll contents in wheat shoots. Biological Planta. 50: 653-659.

[61] Kukier, U.; Peters, C.A.; Chaney, R.L.; Angle, J.S. and Roseberg, R.J. 2004. The effect of $\mathrm{pH}$ on metal accumulation in two Alyssum species. Journal of Environmental Quality. 33: 2090-2102.

[62] Campbell, P.G.C. 2006. Cadmium-A priority pollutant. Environmental Chemistry. 3(6): 387-388.

[63] Hassan, Z. and Aarts, M.G.M. 2011. Opportunities and feasibilities for biotechnological improvement of $\mathrm{Zn}, \mathrm{Cd}$ or $\mathrm{Ni}$ tolerance and accumulation in plants. Environmental and Experimental Botany. 72(1): 53-63.

[64] Pilon-Smits, E. 2005. Phytoremediation, Annual Review of Plant Biology. 56: 15-39.

[65] Blaylock, M.J. and Huang, J.W. 2005. Phytoextraction of metals, in phytoremediation of toxic metals using plants to clean up the environment (Eds.: I. Raskin, B. D. Ensley) Wiley, New York. 53-70.

[66] Nawab, J.; Khan, S.; Tahir Shah, M.T.; Gul, N.; Ali, A.; Khan, K. and Huang, Q. 2016. Heavy metal bioaccumulation in native plants in chromite impacted sites: A search for effective remediating plant species. Clean-Soil, Air, Water. 44 (1): 37-46. 